\title{
Determination of the Effect of Two Different Methods of Dental Anaesthesia on Pain Level in Pediatric Patients: A Cross-Over, Randomised Trial
}

\author{
Nagehan Yilmaz ( $\square$ nagehany89@yahoo.com ) \\ Karadeniz Teknik Üniversitesi: Karadeniz Teknik Universitesi \\ Ozgul Baygin \\ Karadeniz Teknik Üniversitesi: Karadeniz Teknik Universitesi \\ Tamer Tüzüner \\ Karadeniz Teknik Üniversitesi: Karadeniz Teknik Universitesi \\ Ahmet Menteşe \\ Karadeniz Teknik Üniversitesi: Karadeniz Teknik Universitesi \\ Selim Demir \\ Karadeniz Teknik Üniversitesi: Karadeniz Teknik Universitesi
}

\section{Research Article}

Keywords: Intraosseous, Needle-free injection, Opiorphin, Spielberger

Posted Date: January 3rd, 2022

DOI: https://doi.org/10.21203/rs.3.rs-1204789/v1

License: (c) (1) This work is licensed under a Creative Commons Attribution 4.0 International License. Read Full License 


\section{Abstract}

Objective

To compare intraosseous (IOA) and needle-free dental anaesthesia (NFA) methods that painless anaesthesia.

Materials and Methods

Twenty patients aged 8-10 years were included in this cross-over study. To determine the anxiety levels and pain experienced by the patients, Face, Legs, Activity, Cry, Consolability (FLACC) and Frankl Behavioural scales were used. The pulse rate (PR) and salivary opiorphin levels (SOL) determined. The Friedman and Wilcoxon signed-rank tests were used. $p<0.01$ was considered significant.

Results

According to FLACC scores, IOA and NFA exhibited significantly pain alteration patterns in during local and topical anaesthesia, respectively $(\mathrm{p}=0.004,0.001$; $\mathrm{p}<0.01$ ). Also, only NFA showed significantly decreased SOL values in 5 - and 10 - minutes after local anaesthesia periods compared to the before levels $(p=0.004, p=0.001 ; p<0.01)$.

Conclusions

Patients feel similar pain perceptions during local anaesthesia application in both injection systems. According to the SOL values, NFA may provide more higher anaesthetic efficiency than IOA.

Clinical Relevance

This study provides to compare two different new anaesthetic systems for pain reduction during local anesthesia for pediatric population.

\section{What Is Known}

- NFA system has similar results with conventional needle.

- IOA system is as more effect as conventional needle.

\section{What is new}

- It is the first study that compare to NFA and IOA systems.

- NFA and IOA systems has similar results for felt pain level.

\section{Introduction}

Dental treatments are often associated with pain but their patient acceptance has been facilitated by hypodermic injection of procaine and lidocaine amide as anesthetic agents. However, many patients associate pain with injection due to mechanical trauma of needle insertion or the sudden stretching of tissues by anesthesia during rapid release of the anesthetic [1].

According to the American Dental Association, fear of pain can prevent patients from visiting their dentists also local anesthetic injection is the most anxietyinducing procedure for patients [1]. Painless anaesthesia is a critical issue in terms of increasing the patients' trust in the physician during any procedure. However, a child's feeling of anxiety during dental treatment may lead to maladaptive behaviours that may hinder and delay the treatment [2,3]. Therefore, especially in pediatric dentistry, ways to avoid the invasive and often painful nature of injection are being investigated [4]. Different measures to reduce discomfort associated with an injection have been tried like that using of topical anaesthetic, warming anaesthesia solution to body temperature using of lowlevel laser or another local anaesthetic delivery methods $[1,5]$.

Computer-controlled local anaesthetic delivery systems (CCLAD), SleeperOne ${ }^{\mathrm{TM}}$, Wand [6] and Comfort-In ${ }^{\mathrm{TM}}$, which provides anaesthesia using pressure, can be regarded as new systems that have been developed to perform local analgesic injection while overcoming the shortcomings of traditional infiltration procedures. SleeperOne ${ }^{T M}$ is a new type of CCLAD with a persistent resistance system analysis that regulates injection according to tissue density [4]. Unlike traditional needle syringe injection methods, it was indicated by the manufacturer that the infiltration anaesthesia injection of Comfort-In ${ }^{T M}$ provides local anaesthesia by penetrating below the periosteum [7].

Although previous studies have generally compared traditional techniques and CCLAD systems using behavioural and pain scales, [8,9] a comparative study of Comfort-In ${ }^{\mathrm{TM}}$, a new needle-free anaesthesia (NFA) method, and SleeperOne ${ }^{\mathrm{TM}}$, an effective CCLAD method, is not available in the literature. In addition, in the literature review, no study was found in which the effect of anaesthesia methods on pain sensation was compared using a 'cross-over' research design by obtaining both biological, physiological and observational data from the patients with the aim of evaluating the effect of newly developed anaesthesia methods on pain levels in patients. Therefore, the project we designed is innovative compared to other studies.

\section{Hypothesis:}


No difference in pain levels of systemically healthy 8-10-year-old patients will be observed during local anaesthesia performed as the intraosseous anaesthesia (IOA) or NFA.

\section{Materials And Methods}

After obtaining the ethics committee approval from XXX Faculty of Medicine Clinical Research Ethics Committee for the study (approval number 2019/699) (Annex 1), the approval of the XXX Medicines and Medical Devices Agency of the XXX Ministry of Health was obtained (approval number 71146310-511.06E.204453) (Annex 2). It is registered at ClinicalTrials.gov (NCT05002673).

\section{Sample size determination}

The sample size was determined based on the study conducted by Campanella et al. [1] with an effect size $=0.5$, alpha error $=0.05$ and beta error $=0.20$, it was determined that a total of 35 samples were needed and considering possible losses, a total of 40 patients were found to be sufficient. Since the study was designed as a 'cross-over'study, 20 patients were included in the study.

\section{Patient selection}

Patients aged 8-10 years, who were systemically healthy, without any physical or psychological disorders, did not use any medication, had undergone dental treatment (except for extraction) previously but with at least 1 week passed since then, had never tried IOA and NFA anaesthesia techniques before, were not undergoing any orthodontic or ongoing dental treatment (e.g. Root canal therapy), were compatible enough to undergo therapy in the clinic in a sitting position, had infection between the roots with a rate over $1 / 3$, had $2 / 3$ root formation, had been indicated for extraction of the maxillary primary molar teeth (55/65 No. teeth), [10] and did not have acute and/or subacute infection of the related or other teeth or mouth and surrounding tissues were included in the study. Further, patients who scored above 41 in the state anxiety subscale and above 44 in the trait anxiety subscale [11] of the Spielberger State-Trait Anxiety Scale (SSAS-SAAS) were not included in the study.

In this study, fourty patients' legal representatives that suitable for including criteria and coming university dental hospital paediatric clinic between September 2020 and January 2020 were interviewed. Among them nine patients did not accept to attend study. After the procedures were started, five patients were withdrawn from the study voluntarily, while four patients were excluded due to cooperation problems. Addition, although the patients were excluded from the study due to data loss in the video recordings of 2 patients, the study was completed patients with a number suitable for the sample size ( $\mathrm{n}=20)$ (Fig. 1).

\section{Randomisation}

Twenty patients who presented to the clinic, met the inclusion criteria and agreed to participate in the study were assigned numbers from 1 to 20 , respectively. Subsequently, patient numbers were randomly distributed using a computer-assisted randomization [12] programme. According to the sequence number of the patients, envelopes containing details about the application group (i.e., which anaesthesia method would be applied first) were chosen by each patient in a blinded manner. Accordingly, the first procedure to be applied to that patient was decided.

\section{Study design}

A cross-over design that in which two or more treatments are applied to the same patient within the framework of a plan was used in this study [13]. An informed consent form was obtained from all patients included in the study and their parents before the procedure. Patients included in the study were taken to isolated single rooms around 9-10 am. The patients were asked to feed and brush their teeth approximately 1 hour before the dental procedure.

SSAS-SAAS was administered by the principal investigator to determine the patients' state and trait anxiety levels before the procedure. The SSAS-SAAS scale consisted of two separate scales included of 20 questions each, state and trait, and each question was scored from 1 (not at all) to 4 (completely). The scales included direct and reversed statements like "I am currently calm" and "I usually get tired quickly" [14].

Subsequently, like in every patient who presented to the pediatric dentist clinic, the tell-show-do behaviour guidance technique was used and unstimulated saliva samples were passively taken three times from the floor of the mouth of each patient using a Pasteur pipette: 15 minutes (min) before dental anaesthesia, $5 \mathrm{~min}$ after dental anaesthesia and $10 \mathrm{~min}$ after dental anaesthesia $[15,16]$. A pulse metre (Yonker Fingertip Pulse Oximeter, Prolinx GmbH, Germany) was attached to the patient's right index finger $15 \mathrm{~min}$ before the procedure as an indicator showing the relationship of heart rate (measured as pulse rate $(P R))$ with pain.

During dental anaesthesia with two systems, 4\% articaine 1/100.000 (Ultracain DS Forte Ampul, Articaine HCl 40 mg/ml Epinephrine HCl 0.012 mg/ml, PharmaVision San. ve Tic. A.Ş., Turkey) [17] in ampoule and carpule forms were used. No topical anaesthetic was applied before anaesthesia. All anaesthesia procedures and tooth extraction treatments were performed by the same researcher who had 1 month of experience using Comfort-ln ${ }^{\text {TM }}$ (Mika Medical; Busan, Korea) and SleeperOne ${ }^{\mathrm{TM}}$ (DHT, Cholet, France) injection systems.

The Frankl and the FLACC scores were determined by the two calibrated pediatric dentists, who did not perform the procedure, to objectively evaluate the patient's behaviours and pain levels before the treatment, during the administration of local anaesthesia, and during and after the treatment, based on the video recordings of the patients. Before the study these two pediatric dentists evaluated FLACC and Frankl scales on 10 patients that independent of the study group, and the interobserver agreement was found to be good ( $\mathrm{k}=0.729)$. In addition, the Wong-Baker Faces Pain Rating Scale (WB) that included faces describing pain from 0 (no pain) to 10 (unbearable pain) was used before the procedure, immediately after anaesthesia, immediately after extraction and 15 min after the procedure to analyse the subjective pain felt by the children [18]. The FLACC scale graded five pain-related behaviours with 0,1 , or 2 points, and an increase in the score indicated the presence of pain. The Frankl Behavioural Scale rated children's behaviour in dental treatments from 1 (absolutely 
negative) to 4 (absolutely positive). However, all scales (SSAS-SAAS, FLACC, Frankl, WB) were used in the study were used in other studies in Turkish validated format $[14,19]$.

The same parameters were tested 1 week later while performing the left/right upper tooth extraction using the dental anaesthesia technique that had not been applied in the first session based on randomisation in each patient (Fig. 1).

\section{IOA anaesthesia procedure}

The installation of the SleeperOne ${ }^{\mathrm{TM}}$ (DHT, Cholet, France) anaesthesia device (needle diameter and length, 30 Gauge/9 mm, a double row needle that provides better penetration into the bone) [20] was made in accordance with the manufacturer's instructions. Before local anaesthesia, 1-2 drops of articaine solution was applied to the buccal region after superficially passing the epithelium for topical purposes, and then the IOA method was used. IOA was performed directly on the interproximal bone between the two teeth. By approaching from the buccal part, the needle was gently pushed into the cortical bone under the interdental papilla at an angle of $45^{\circ}$ with clockwise and counter clockwise movements,[4] and a total of half carpule (1 cc) of the anaesthetic was administered (Fig. 2).

\section{NFA anaesthesia procedure}

Likewise, the installation of the Comfort-In ${ }^{\mathrm{TM}}$ (Mika Medical; Busan, Korea) anaesthesia device was performed in accordance with the manufacturer's instructions. Before anaesthesia, 1 shot of $0.1 \mathrm{ml}$ was applied to the buccal and palatal regions for topical purposes, and after 10-15 seconds of anaesthesia, 2 shots of $0.3 \mathrm{ml}$ each to the buccal region and 2 shots of $0.1 \mathrm{ml}$ each to the palatal region were administered (total $1 \mathrm{cc}$ [ [7] (Fig. 3).

\section{Obtaining saliva samples}

Saliva samples were taken from the individuals in the patient group in a biochemistry tube with separator gel. Consent forms were collected along with the saliva samples. The tubes were centrifuged at $1800 \times \mathrm{g}$ for $10 \mathrm{~min}$. After centrifugation, the supernatants were carefully transferred to capped microfuge tubes and stored at $-80^{\circ} \mathrm{C}$ until analysis. The saliva samples were brought to room temperature and thawed before analysis. The thawed samples were homogenised by vortexing and the biochemical parameters were measured.

\section{Determining opiorphin levels}

SOL was determined using the enzyme-linked immunosorbent assay (ELISA) kit (Cusabio, Cat No: CSB-EQ027423HU, Wuhan, China) [21] in accordance with the manufacturer's instructions. The opiorphin standards $(40-0.625 \mathrm{ng} / \mathrm{mL})$ were prepared according to the kit-specified procedure. Absorbances of the samples and standarts were measured at $450 \mathrm{~nm}$ using a microplate reader spectrophotometer (Versamax, Molecular Devices, California, USA). Each sample was analysed in duplicate, and their results were averaged and presented in $\mathrm{ng} / \mathrm{mL}$ units. The intra-assay repeatability (\%CV) of the ELISA kit used was calculated as $3.2 \%(n=20)$.

\section{Statistical analysis}

A statistical data programme was used for statistical analyses. Descriptive values were assigned to sex and age. Descriptive values were expressed as mean \pm standard deviation, median (minimum-maximum) or \% values. Cohen's Kappa value was calculated for inter-observer agreement. Normal distribution of the data was evaluated using the Shapiro-Wilk test. The Friedman and Wilcoxon signed-rank tests and Bonferroni correction were applied for both continuous (SOL, PR and SSAS-SAAS scores) and categorical variables (WB, Frankl and FLACC scores). In all analyses, a p-value of $<0.05$ was considered statistically significant.

\section{Blinding}

The Frankl Behavioural Scale and the Face, Legs, Activity, Cry, Consolability (FLACC) Scale datas were scored from the video recording images of the procedure by two other pediatric dentist researchers who were blinded to the applied techniques. The researchers who determined the levels of opiorphin in the collected saliva and performed the statistical analyses blinded to the grouping of the patients. Although the patients had partial awareness of the technique applied, since all evaluations were performed on video recordings, the risk of subjective results during the pain scoring of the patients was avoided and objective blinding could be established.

\section{Results}

In the study, there were 2 patients aged 8 years, 7 patients aged 9 years and 11 patients aged 10 years. Further, 8 (40\%) of the patients were girls and 12 (60\%) were boys (Table1). 
Table 1

Age and gender distributions of patients

\begin{tabular}{|c|c|c|c|c|}
\hline & \multicolumn{4}{|c|}{$n(\%)$} \\
\hline \multirow[t]{4}{*}{ Age } & Median(min-max) & 8 & 9 & 10 \\
\hline & $10(8-10)$ & & & \\
\hline & Mean $\pm S D$ & $2(10)$ & $7(35)$ & $11(55)$ \\
\hline & $9.45 \pm .686$ & & & \\
\hline \multirow{2}{*}{\multicolumn{2}{|c|}{ Gender }} & Girl & \multicolumn{2}{|c|}{ Boy } \\
\hline & & $8(40)$ & \multicolumn{2}{|c|}{$12(60)$} \\
\hline
\end{tabular}

\section{SOL, PR and SSAS-SAAS scores}

According to SSAS-SAAS scores there were not statistically significant difference in state and trait anxiety of patients between two sessions. ( $p=0.636$; $\mathrm{p}>0.05$ ). According to the statistically significant decreases PRs suggested that patient may have felt more comfortable with NFA than IOA method during extraction $(p=0.002 ; p<0.01)$. For the NFA method, the significant decrease in the SOL at 5 - and 10 -min anaesthesia showed the effectiveness of anaesthesia $(p=0.004, p=0.001 ; p<0.01)$ (Table 2).

Table 2

Time-dependent changes in Spielberg trait-state anxiety scale scores, opiorphine values and puls rate values for two different anesth

\begin{tabular}{|c|c|c|c|c|c|c|c|c|c|}
\hline Anesthesia & Spielberg & Spielberg & Opiorphin & Opiorphin & Opiorphin & Puls rate & Puls rate & Puls rate & Puls rate \\
\hline \multirow[t]{5}{*}{ Type } & State score & Trait score & value & value & value & \multirow{5}{*}{$\begin{array}{l}15 \text { minutes } \\
\text { before local } \\
\text { anesthesia } \\
\text { Median(min- } \\
\text { max) }\end{array}$} & \multirow{5}{*}{$\begin{array}{l}\text { During } \\
\text { topical } \\
\text { anesthesia } \\
\text { Median(min- } \\
\text { max) }\end{array}$} & \multirow{5}{*}{$\begin{array}{l}\text { During local } \\
\text { anesthesia } \\
\text { Median(min- } \\
\text { max) }\end{array}$} & \multirow{5}{*}{$\begin{array}{l}\text { During } \\
\text { extraction } \\
\text { Median(mi } \\
\text { max) }\end{array}$} \\
\hline & \multirow{4}{*}{$\begin{array}{l}\text { Median(min- } \\
\text { max) }\end{array}$} & \multirow{4}{*}{$\begin{array}{l}\text { Median(min- } \\
\text { max) }\end{array}$} & \multirow{4}{*}{$\begin{array}{l}15 \text { minutes } \\
\text { before local } \\
\text { anesthesia } \\
\text { Median(min- } \\
\text { max) }\end{array}$} & \multirow{4}{*}{$\begin{array}{l}5 \text { minutes } \\
\text { after local } \\
\text { anesthesia } \\
\text { Median(min- } \\
\text { max) }\end{array}$} & 10 minutes & & & & \\
\hline & & & & & & & & & \\
\hline & & & & & anesthesia & & & & \\
\hline & & & & & $\begin{array}{l}\text { Median(min- } \\
\text { max) }\end{array}$ & & & & \\
\hline Intraosseous & $34(28-41)$ & $\begin{array}{l}\mathrm{m}_{28.5(20-} \\
41)\end{array}$ & $\begin{array}{l}17.85(7.4- \\
36.50)\end{array}$ & $15.10(3-40)$ & $\begin{array}{l}19.05(7.6- \\
39.7)\end{array}$ & 107(87-144) & $\begin{array}{l}99.4(71.5- \\
133.1)\end{array}$ & $\begin{array}{l}b_{1} 101.15(80.3- \\
142.4)\end{array}$ & $\begin{array}{l}99.05(80.8 \\
205.4)\end{array}$ \\
\hline Needle-free & $34(28-41)$ & $\mathrm{n}_{31(20-41)}$ & $\begin{array}{l}\mathrm{d}_{23.1(5.1-} \\
42.6)\end{array}$ & $\begin{array}{l}c_{15.7(2.7-} \\
28.8)\end{array}$ & $\begin{array}{l}\mathrm{e}_{16.55(4.4-} \\
34)\end{array}$ & $\begin{array}{l}\text { 9106(89- } \\
134)\end{array}$ & $\begin{array}{l}\mathbf{j}_{109(84.5-} \\
137.8)\end{array}$ & $\begin{array}{l}\mathrm{k}_{109.75(80.8-} \\
129)\end{array}$ & 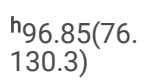 \\
\hline
\end{tabular}

$\mathrm{m}_{-}{ }_{\mathrm{p}} \mathrm{p}=0.636 ; \mathrm{p}>0.05$ Wilcoxon Signed Ranks Test, ${ }^{\star} \mathrm{p}<0.01$ Friedman Wilcoxon Signed Ranks Test test, Bonferroni Correction

\section{Wong-Baker, Frankl and FLACC scale scores}

Significant increases in FLACC during local anaesthesia showed the presence of pain during local anaesthesia for the IOA method ( $p=0.004 ; p<0.01)$. For the NFA method, the increase in the FLACC scores during topical anaesthesia showed that the pain during topical anaesthesia ( $p=0.001 ; p<0.01)$. In addition, for the NFA method, a significant increase in the WB value in immediately after the extraction showed the presence of pain during the extraction ( $p=0.002$; $p<0.001)$ (Table 3,4,5). 
Table 3

Time-dependent changes in Wong Baker scores for two different anesthesia type

\begin{tabular}{|c|c|c|c|c|c|c|c|c|c|c|c|c|c|c|c|c|}
\hline Anesthesia & \multicolumn{3}{|c|}{ WB score } & \multicolumn{4}{|c|}{ WB score } & \multicolumn{5}{|c|}{ WB score } & \multicolumn{4}{|c|}{ WB score } \\
\hline \multirow[t]{2}{*}{ Type } & \multicolumn{3}{|c|}{$\begin{array}{l}15 \text { min before local } \\
\text { anesthesia }\end{array}$} & \multirow{2}{*}{\multicolumn{4}{|c|}{$\begin{array}{l}\text { After local anesthesia } \\
(0 / 2 / 4 / 6 / 8 / 10)\end{array}$}} & \multirow{2}{*}{\multicolumn{5}{|c|}{$\begin{array}{l}\text { Right after extraction } \\
(0 / 2 / 4 / 6 / 8 / 10)\end{array}$}} & \multirow{2}{*}{\multicolumn{4}{|c|}{$\begin{array}{l}15 \text { min after extraction } \\
(0 / 2 / 4 / 6 / 8 / 10)\end{array}$}} \\
\hline & \multicolumn{3}{|c|}{$(0 / 2 / 4 / 6 / 8 / 10)$} & & & & & & & & & & & & & \\
\hline \multirow[t]{5}{*}{ Intraosseous } & \multicolumn{3}{|l|}{$\mathrm{n}(\%)$} & \multicolumn{4}{|l|}{$n(\%)$} & \multicolumn{5}{|l|}{$n(\%)$} & \multicolumn{4}{|l|}{$n(\%)$} \\
\hline & 0 & 2 & 4 & 0 & 2 & 4 & 10 & 0 & 2 & 4 & 6 & 8 & 0 & 2 & & 4 \\
\hline & $17(85)$ & $1(5)$ & $2(10)$ & $8(40)$ & $8(40)$ & $3(15)$ & $1(5)$ & $1(5)$ & $8(40)$ & $7(35)$ & $3(15)$ & $1(5)$ & $8(40)$ & $6(30)$ & & $5(2 \leftleftarrows$ \\
\hline & \multicolumn{3}{|c|}{ Median(min-max) } & \multicolumn{4}{|c|}{ Median(min-max) } & \multicolumn{5}{|c|}{ Median(min-max) } & \multicolumn{4}{|c|}{ Median(min-max) } \\
\hline & \multicolumn{3}{|l|}{ a $0(0-4)$} & \multicolumn{4}{|c|}{$2(0-10)$} & \multicolumn{5}{|c|}{$\mathrm{b}_{4}(0-8)$} & \multicolumn{4}{|l|}{$2(0-6)$} \\
\hline \multirow[t]{5}{*}{ Needle-free } & \multicolumn{3}{|l|}{$\mathrm{n}(\%)$} & \multicolumn{4}{|l|}{$\mathrm{n}(\%)$} & \multicolumn{5}{|l|}{$\mathrm{n}(\%)$} & \multicolumn{4}{|l|}{$\mathrm{n}(\%)$} \\
\hline & 0 & 2 & & 0 & 2 & & 10 & 0 & 2 & 4 & 6 & 10 & 0 & 2 & 4 & \\
\hline & 18(90) & 2 & 10) & $10(50)$ & 9( & & $1(5)$ & $2(10)$ & $9(45)$ & $7(35)$ & $1(5)$ & $1(5)$ & $8(40)$ & $8(40)$ & $3(15)$ & \\
\hline & \multicolumn{3}{|c|}{ Median(min-max) } & \multicolumn{4}{|c|}{ Median(min-max) } & \multicolumn{5}{|c|}{ Median(min-max) } & \multicolumn{4}{|c|}{ Median(min-max) } \\
\hline & \multicolumn{3}{|l|}{ d $0(0-2)$} & \multicolumn{4}{|c|}{$f_{1}(0-10)$} & ${ }^{c} 2(0-1$ & & & & & ${ }^{e} 2(0-6)$ & & & \\
\hline
\end{tabular}

${ }^{\star} \mathrm{p}<0.01$ Friedman Wilcoxon Signed Ranks Test test, Bonferroni Correction

Table 4

Time-dependent changes in FLACC scores for two different anesthesia type

\begin{tabular}{|c|c|c|c|c|c|c|c|c|c|c|c|c|c|c|c|c|}
\hline Anesthesia & \multicolumn{3}{|c|}{ FLACC score } & \multicolumn{4}{|c|}{ FLACC score } & \multicolumn{5}{|c|}{ FLACC score } & \multicolumn{4}{|c|}{ FLACC score } \\
\hline Type & \multicolumn{3}{|c|}{$\begin{array}{l}15 \text { min before local } \\
\text { anesthesia }\end{array}$} & \multicolumn{4}{|c|}{$\begin{array}{l}\text { During topical anesthesia } \\
(0-10)\end{array}$} & \multicolumn{5}{|c|}{$\begin{array}{l}\text { During local anesthesia } \\
(0-10)\end{array}$} & \multicolumn{4}{|c|}{$\begin{array}{l}\text { During extraction } \\
(0-10)\end{array}$} \\
\hline \multirow[t]{5}{*}{ Intraosseous } & \multicolumn{3}{|l|}{$\mathrm{n}(\%)$} & \multicolumn{4}{|l|}{$\mathrm{n}(\%)$} & \multicolumn{5}{|l|}{$\mathrm{n}(\%)$} & \multicolumn{4}{|l|}{$\mathrm{n}(\%)$} \\
\hline & 0 & \multicolumn{2}{|l|}{1} & 0 & 1 & 2 & 3 & 0 & 1 & 3 & 4 & 6 & 0 & \multicolumn{2}{|l|}{2} & 3 \\
\hline & $17(85)$ & \multicolumn{2}{|c|}{$3(15)$} & $13(65)$ & $4(20)$ & $1(5)$ & $2(10)$ & $8(40)$ & $4(20)$ & $3(15)$ & $4(20)$ & $1(5)$ & $7(35)$ & \multicolumn{2}{|c|}{$3(15)$} & $1(!$ \\
\hline & \multicolumn{3}{|c|}{ Median(min-max) } & \multicolumn{4}{|c|}{ Median(min-max) } & \multicolumn{5}{|c|}{ Median(min-max) } & \multicolumn{4}{|c|}{ Median(min-max) } \\
\hline & \multicolumn{3}{|l|}{$\mathrm{b}_{0}(0-1)$} & \multicolumn{4}{|l|}{$0(0-3)$} & \multicolumn{5}{|c|}{$a_{1}(0-6)$} & \multicolumn{4}{|c|}{$c_{2.5(0-6)}$} \\
\hline \multirow[t]{5}{*}{ Needle-free } & \multicolumn{3}{|l|}{$\mathrm{n}(\%)$} & \multicolumn{4}{|l|}{$\mathrm{n}(\%)$} & \multicolumn{5}{|l|}{$\mathrm{n}(\%)$} & \multicolumn{4}{|l|}{$\mathrm{n}(\%)$} \\
\hline & 0 & 1 & 2 & 0 & 1 & & 2 & 0 & 1 & & 2 & & 0 & 1 & 2 & \\
\hline & $15(75)$ & $4(20)$ & $1(5)$ & $4(20)$ & $8(40$ & & $8(40)$ & $6(30)$ & & (60) & & & $6(30)$ & $6(30)$ & $2(10)$ & \\
\hline & \multicolumn{3}{|c|}{ Median(min-max) } & \multicolumn{4}{|c|}{ Median(min-max) } & \multicolumn{5}{|c|}{ Median(min-max) } & \multicolumn{4}{|c|}{ Median(min-max) } \\
\hline & \multicolumn{3}{|l|}{$\mathrm{f}^{0}(0-2)$} & $\mathrm{e}_{1}(0-2)$ & & & & $\mathrm{j}_{1(0-2)}$ & & & & & $\mathbf{g}_{1(0-6)}$ & & & \\
\hline
\end{tabular}


Table 5

Time-dependent changes in Frankl scores for two different anesthesia type

\begin{tabular}{|c|c|c|c|c|c|c|c|c|c|c|c|c|c|}
\hline \multirow{2}{*}{$\begin{array}{l}\text { Anesthesia } \\
\text { Type }\end{array}$} & \multicolumn{2}{|c|}{ FRANKL score } & \multicolumn{3}{|c|}{ FRANKL score } & \multicolumn{3}{|c|}{ FRANKL score } & \multicolumn{3}{|c|}{ FRANKL score } & FRANKL score & \multirow[t]{2}{*}{$p$} \\
\hline & \multicolumn{2}{|c|}{$\begin{array}{l}15 \text { min before local } \\
\text { anesthesia } \\
(1-4)\end{array}$} & \multicolumn{3}{|c|}{$\begin{array}{l}\text { During topical } \\
\text { anesthesia }\end{array}$} & \multicolumn{3}{|c|}{$\begin{array}{l}\text { During local anesthesia } \\
(1-4)\end{array}$} & \multicolumn{3}{|c|}{$\begin{array}{l}\text { During extraction } \\
(1-4)\end{array}$} & $\begin{array}{l}15 \text { min after } \\
\text { extraction } \\
(1-4)\end{array}$ & \\
\hline \multirow[t]{4}{*}{ Intraosseous } & \multicolumn{2}{|l|}{$\mathrm{n}(\%)$} & \multicolumn{3}{|l|}{$\mathrm{n}(\%)$} & \multicolumn{3}{|l|}{$\mathrm{n}(\%)$} & \multicolumn{3}{|l|}{$n(\%)$} & $\mathrm{n}(\%)$ & \multirow{2}{*}{$\begin{array}{l}a-b \\
p=0.004\end{array}$} \\
\hline & 3 & 4 & 3 & 4 & & 3 & 4 & & 2 & 3 & 4 & 4 & \\
\hline & $4(20)$ & 16(80) & $4(20)$ & 1 & $5(80)$ & $9(45)$ & & (55) & $1(5)$ & $12(60)$ & $7(35)$ & $20(100)$ & $\begin{array}{l}c-e \\
p=0.003\end{array}$ \\
\hline & \multicolumn{2}{|l|}{$4(3-4)$} & \multicolumn{3}{|c|}{$b_{4}(3-4)$} & \multicolumn{3}{|c|}{$e_{4(3-4)}$} & $\begin{array}{l}\text { Medi } \\
\text { a3(2- }\end{array}$ & n(min-m & & $\begin{array}{l}\text { Median(min- } \\
\text { max) } \\
{ }^{\mathrm{c}} 4(4-4)\end{array}$ & $\begin{array}{l}c-a \\
p<0.001\end{array}$ \\
\hline \multirow[t]{4}{*}{ Needle-free } & \multicolumn{2}{|l|}{$\mathrm{n}(\%)$} & \multicolumn{3}{|l|}{$\mathrm{n}(\%)$} & \multicolumn{3}{|l|}{$\mathrm{n}(\%)$} & \multicolumn{3}{|l|}{$\mathrm{n}(\%)$} & $\mathrm{n}(\%)$ & \multirow{4}{*}{$\begin{array}{l}d-f \\
p=0.004 \\
d-g_{p}=0.002\end{array}$} \\
\hline & 3 & 4 & 2 & 3 & 4 & 2 & 3 & 4 & 2 & 3 & 4 & 4 & \\
\hline & $4(20)$ & 16(80) & $1(5)$ & $8(40)$ & $11(55)$ & $2(10)$ & $4(20)$ & $14(70)$ & $1(5)$ & $9(45)$ & $10(50)$ & $20(100)$ & \\
\hline & $\begin{array}{l}\text { Media } \\
4(3-4)\end{array}$ & n-max) & $\begin{array}{l}\text { Medi } \\
f_{4}(2-4\end{array}$ & $n(\min -n$ & hax) & $\begin{array}{l}\text { Media } \\
4(2-4)\end{array}$ & $(\mathrm{min}-\mathrm{m}$ & & $\begin{array}{l}\text { Medi } \\
\mathbf{g}_{3.5(2}\end{array}$ & $n(\min -m$ & & $\begin{array}{l}\text { Median(min- } \\
\max )\end{array}$ & \\
\hline
\end{tabular}

\section{Discussion}

One of the most important factors affecting success in pediatric dentistry is pain control [22,23]. In the literature, methods such as the use of computercontrolled anaesthesia delivery systems, modern devices and new NFA systems have been investigated to reduce anaesthesia-induced pain [23,24]. However, according to our knowledge, no study has evaluated the effects of IOA and NFA methods on patients' pain levels. Therefore, this study was designed and conducted to eliminate this research gap and to compare two different advanced dental anaesthesia devices.

In this study, the cross-over design was preferred as it eliminates subject variability and allows greater biological homogeneity [13]. The reason for choosing children aged $8-10$ years was that there are studies $[18,23,24]$ reporting that the scales used herein are reasonable and reliable for children in this age group. $[17,25,26]$ In addition, the tooth extraction treatment was chosen in this study because of it was most painful procedure for children $[27,28]$.

WB, which was developed for the subjective assessment of pain, is an easy-to-use scale with adequate psychometric properties [18]. FLACC, one of the scales used in pain measurement, has been shown to have excellent validity and reliability for the objective assessment of pain in young or cognitively sound children [29]. In this study, WB and FLACC were used to evaluate children's pain behaviours both subjectively and objectively, taking advantage of both these scales. The general anxiety level of the individuals may affect the specific anxiety level related to the procedure [14]. Baygin et al. [14] evaluated the relationship between pre-procedural anxiety level and perceived pain level during the procedure in children undergoing tooth extraction and reported that the measured anxiety levels were correlated with each other [14]. In this study, SSAS-SAAS was used to determine state and trait anxiety levels of the patients when they came to the clinic, and the Frankl Behavioural Scale was used to evaluate the anxiety status throughout the procedure. While the trait anxiety subscale scores of the patients included in the study did not change due to the cross-over study design, the absence of a statistically significant difference between the state anxiety subscale scores between sessions $(p=0.636 ; p>0.05)$ suggested that the initial anxiety levels of the patients were similar. This outcome may have simplified to compare the anaesthesia methods during the study period.

In addition to the pain and anxiety scales used in the study, PR $[1,30]$ and SOL, which are physiological and biological markers [28] that indirectly measure pain and anxiety, [15,31] were used to obtain measurements independent of observer bias or subjective reporting of the patient [1]. Similarly, there are studies in the literature that have used PR $[1,28]$ and SOL $[15,16,31]$ to analyse pain and anxiety.

The hypothesis of the study that there would be no difference in felt pain during local anaesthesia between IOA and NFA systems is partially accepted. According to increases FLACC scores during local and topical anaesthesia, IOA and NFA systems produced pain during local and topical anaesthesia, respectively. However, the increase in FLACC during local and topical anaesthesia with IOA and NFA systems may also have occurred owing to the fear of injection [27]. Although it was not statistically significant, two methods showed similar patterns of change according to the Frankl, WB and PRs.

According to our knowledge as there is no study in the literature that compares IOA and NFA systems, it may not be appropriate to compare the results of this study entirely. In general, studies in the literature have compared traditional injection and CCLAD, they report that CCLAD to be more advantageous [2,32,33]. However, there are also studies that did not find a statistical difference between the two injection methods [17,25,34].

IOA has high efficacy rates, but it is rarely used in young patients [36]. In previous studies conducted on adults that compared IOA with conventional syringes and computerised devices, pain ratings were found to be higher in the early stages of the traditional procedure than in the computerised procedure [36]. Pain due to osseous perforation was mild to moderate in $8-78 \%$ and severe in $0-15 \%$ of patients $[35,36]$. In a study by Sixou et al., [35] in which they compared IOA 
and conventional anaesthesia, they noted symptoms of pain/discomfort during mucosal anaesthesia and bone perforation, but these findings were not associated with high pain scores. The findings of pain/discomfort during IOA in patients can be considered as a result similar to the patient's feeling of pain during local anaesthesia in this study. Because of the device used in the study by Sixou et al. [35] was an advanced model of SleeperOne ${ }^{\mathrm{TM}}$, it can be assumed that their results are not entirely comparable with the results of this study.

A study by Versloot et al. [37] found that using CCLAD (Wand) did not provide any benefit compared to traditional injection as it creates additional discomfort for the child owing to the long injection time in extremely anxious children. Wand is one of the CCLAD similar to SleeperOne ${ }^{T M}$ [4]. Nieuwenhuizen et al. [4] compared Wand and SleeperOneTM in their study. They found no significant difference in pain between two devices but the duration of anaesthesia injection for SleeperOneTM was shorter than that for Wand. Although no measurements were made in this study, it can be thought that the longer duration of anaesthesia injection in the SleeperOne ${ }^{\mathrm{TM}}$ injection method [38] may have been affected the patient's feeling of pain during local anaesthesia.

In this study, the statistically significant decrease in the SOL for the NFA system, both 5 min and 10 min after anaesthesia, was accepted as important biological data showing the effectiveness of anaesthesia. Similar results were obtained in a study by Parida et al. [15] evaluating the relationship between SOL and the use of different local anaesthetic techniques. They found that SOL increased, albeit not statistically significantly, during anaesthesia techniques that cause more pain compared to other techniques. In a study by Ozdogan et al. [31] evaluating toothache due to endodontic dental diseases and SOL concentrations, it was reported that SOL increased significantly in toothache due to inflammation and a strong correlation was observed between the reported pain level and SOL. The significant decrease in the SOL in this study can be explained that local anaesthetics control pain or the element of psychological relief after the onset of lethargy is involved [15].

In the literature, in studies where NFA method was evaluated, high patient and operator acceptance has been reported [39,40]. There is one study in the literature evaluating the Comfort-In ${ }^{\text {TM }}$ system also the study in question used injection for topical anaesthesia. In the study, Yıldırım et al. [23] reported that the NFA system significantly decreased the pain scores compared to traditional topical anaesthesia methods, but did not significantly affect patient preferences. In our study, for the NFA system, statistically significant increases in scores of the FLACC suggested that the patients were more incompliant and felt more pain during topical anaesthesia. This situation can be supported that NFA requires the use of pressure to rapidly apply the anaesthetic solution to the tissue, indicated by Yıldırım et al. [23]. Hence, a sharp popping sound and a feeling of pressure are experienced during the administration of the anaesthetic solution. Yıldırım et al. [23] also stated that the negative relationship they reported in their study may be related to the discomfort that younger children felt from the pressure sensation from the Comfort-In ${ }^{\text {TM }}$ injection system, and they may have interpreted this as a higher level of pain.

Further, for NFA system, according to the WB scores showed that the patients felt pain during tooth extraction. However, in contrast to WB scores, PRs have decreased during tooth extraction statistically significant for NFA method. In addition, the decreases in SOL, which shows the effectiveness of anaesthesia, was statistically significant in NFA method. Considering these findings, it can be considered valid because of that physiological and biological marker such as SOL results as their measurements are not subject to observer bias or not based on the subjective reporting of the patient [1].

The limitations of this study are that the injection systems used in the study were not compared in terms of post-operative discomfort and patient preferences, and that a conventional dental injection group was not established as a control group. In future studies, these limitations should be addressed with larger patient populations, mostly on the basis of biological and physiological markers.

\section{Conclusion}

1. The results showed that IOA and NFA systems are similar during local anaesthesia.

2. Further, decreases the SOL, which is a robust biological marker, suggested that the NFA system may have provided higher anaesthetic efficiency.

\section{Abbreviation}

Computer-controlled local anaesthetic delivery systems (CCLAD)

enzyme-linked immunosorbent assay (ELISA)

Face, Legs, Activity, Cry, Consolability (FLACC)

intraosseous (IOA)

needle-free dental anaesthesia (NFA)

pulse rate $(\mathrm{PR})$

salivary opiorphin levels (SOL)

Spielberger State-Trait Anxiety Scale (SSAS-SAAS)

Wong-Baker Faces Pain Rating Scale (WB)

\section{Declarations}

Acknowledgements 
Thanks to R.A. Gizem Avci for her contributions.

Funding: The study (219S366) was supported by TUBITAK within the scope of TUBITAK 1002 Rapid Support Program.

Conflicts of interest: All authors declare no competing interests.

Availability of data and material: Not applicable

Code availability: Not applicable

Authors' contributions: N.Y. conceived the ideas; N.Y. collected the data; A.M and S.D. analysed the saliva samples. T.T., O.B., N.Y. analysed and checked the data; and N.Y. led the writing.

Ethics approval: This article reports a study that involved human participants. All the procedures performed in the study involving human participants were in accordance with the ethical standards of the institutional and/or national research committee and with the 1964 Helsinki Declaration and its later amendments or comparable ethical standards.

Consent to participate: Informed consent was obtained from all individual participants included in the study.

Consent for publication: Not applicable

\section{References}

1. Campanella V, Libonati A, Nardi R, Angotti V, Gallusi G, Montemurro E, D'Amario M, Marzo G (2018). Single tooth anesthesia versus conventional anesthesia: a cross-over study. Clin Oral Investig 22(9): 3205-3213 doi: 10.1007/s00784-018-2413-2.

2. San Martin-Lopez AL, Garrigos-Esparza LD, Torre-Delgadillo G, Gordillo-Moscoso A, Hernandez-Sierra JF, de Pozos-Guillen AJ (2005). Clinical comparison of pain perception rates between computerized local anesthesia and conventional syringe in pediatric patients. JOCPD 29(3): 239-243 doi: 10.17796/jcpd.29.3.jgh607/870051882.

3. Bernardi S, Zeka K, Mummolo S, Marzo G, Continenza MA (2013). Development of a new protocol: a macroscopic study of the tongue dorsal surface. IJAE 118(2): 1.

4. Nieuwenhuizen J, Hembrecht EJ, Aartman IH, Krikken J, Veerkamp JS (2013). Comparison of two computerised anaesthesia delivery systems: pain and pain-related behaviour in children during a dental injection. Eur Arch Paediatr Dent 14(1): 9-13 doi: 10.1007/s40368-012-0007-2

5. Ram D, Hermida LB, Peretz B (2002) A comparison of warmed and room-temperature anesthetic for local anesthesia in children. Pediatr Dent 24(4):333336

6. Scientific M (1998). The Wand: Computer controlled anesthesia delivery system (manual). New Jersey: Livingstone p 1-27

7. Enfold Word Press Theme by Kriesi. Diş Hekimliğinde Comfort-in (2018). Comfort-in Türkiye. http://www.comfort-inturkiye.com/dis-hekimligi-2/

8. Libonati A, Nardi R, Gallusi G, Angotti V, Caruso S, Coniglione F, Paglia L (2018). Pain and anxiety associated with Computer-Controlled Local Anaesthesia: systematic review and meta-analysis of cross-over studies. Eur J Paediatr Dent 19: 324-332 doi: 10.23804/ejpd.2018.19.04.14.

9. Mummolo S, Ortu E, Necozione S, Monaco A, Marzo G (2014). Relationship between mastication and cognitive function in elderly in L’Aquila. Int J Clin Exp Med 7(4): 1040-1046.

10. Dean JA, Avery DR, McDonald RE (2010). McDonald and Avery Dentistry for the Child and Adolescent- E-Book. Elsevier Health Sciences.

11. Ercan I, Hafizoglu S, Ozkaya G, Kirli S, Yalcintas E, Akaya C (2015). Examining cut-off values for the state-trait anxiety inventory/examinando los puntajes de corte para elinventario de ansiedad estadorasgo. Revista Argentina de Clinica Psicologica 24(2): 143.

12. Urbaniak G, Plous S (2013). Research randomizer (Version 4.0) [Computer Software]. Available From [Google Scholar], http:// Www.Randomizer.Org

13. Mills EJ, Chan AW, Wu P, Vail A, Guyatt GH, Altman DG. Design, analysis, and presentation of crossover trials. Trials 2009; $10(1): 27$.

14. Baygın Ö, Tüzüner T, Işık B, Arslan İ, Tanrıver M. Preoperatif Anksiyetenin Süt Dişi Çekimi Yapılan Çocuklarda Ağrı Düzeyi ile Korelasyonunun Değerlendirilmesi. J Istanb Univ Fac Dent 2012; 46(1): 32-42.

15. Parida SK, Guruprasad T, Krishnakumar VB, Ravi RP (2018). A study of salivary opiorphin levels using different anesthetic drugs and techniques-A randomized controlled clinical study. J Stomatol Oral Maxillofac Surg 119(3): 169-171 doi: 10.1016/j.jormas.2017.11.017

16. Salarić I, Sabalić M, Alajbeg I (2017). Opiorphin in burning mouth syndrome patients: a case-control study. Clin Oral investig 21(7): 2363-2370 doi: 10.1007/s00784-016-2031-9.

17. Queiroz AM, Carvalho AB, Censi LL, Cardoso CL, Leite-Panissi CR, da Silva RA, de Carvalho FK, Nelson-Filho P, da Silva LA (2015). Stress and anxiety in children after the use of computerized dental anesthesia. Braz Dent J 26: 303-307 doi: 10.1590/0103-6440201300211.

18. Şermet Elbay Ü, Elbay M, Yıldırım S, Kaya E, Kaya C, Uğurluel C, Baydemir C (2016). Evaluation of the injection pain with the use of DentalVibe injection system during supraperiosteal anaesthesia in children: a randomised clinical trial. Int J Paediatr Dent 26(5): 336-345 doi: $10.1111 / i p d .12204$.

19. Şermet Elbay, Ü., Elbay, M., Yıldırım, S., Kaya, E., Kaya, C., Uğurluel, C., Baydemir, C. 2016. "Evaluation of the injection pain with the use of DentalVibe injection system during supraperiosteal anaesthesia in children: a randomised clinical trial”. International journal of paediatric dentistry, 26(5), 336-345.

20. Dental HI TEC Toros Dental, https://www.torosdental.com/index.php/urunler/anestezi-cihazi (2021)

Page $9 / 12$ 
21. Cusabio. Human opiorphin Elisa Kit. https://www.cusabio.com/uploadfile/Ins/2017-10-12/CSB EQ027423HU.pdf

22. Abdelmoniem SA, Mahmoud SA (2016). Comparative evaluation of passive, active, andpassive-active distraction techniques on painperception during local anesthesia administration inchildren. J Adv Res 7(3): 551-556 doi: 10.1016/j.jare.2015.10.001.

23. Yıldııım S, Tokuç M, Aydın MN. The effect of pre-anesthesia with a needle-free system versus topical anesthesia on injection pain of the inferior alveolar nerve block: a randomized clinical trial. Clin Oral investig 2020; 1-7.

24. Sandeep V, Kumar M, Jyostna P, Duggi V. Evaluation of 2- stage injection technique in children. Anesth Prog 2016; 63(1): 3-7

25. Ak AT, Çoğulu D, Ergin E, Atilla E. Çocuklarda süt dişi tedavileri sırasında uygulanan bilgisayar kontrollü anestezi sistemi ile konvansiyonel infiltratif enjeksiyon anestezi yönteminin karşılaştıııması. Aydın Dental Journal 2018; 4(1): 1-8.

26. Kuşcu OO, Akyuz S. Children's preferences concerning the physical appearance of dental injectors. J Dent Child 2006; 73(2): 116-121.

27. Amoudi NA, Feda M, Sharaf A, Hanno A, Farsi N. Assessment of the anaesthetic effectiveness of anterior and middle superior alveolar injection using a computerized device versus traditional technique in children. JOCPD 2008; 33(2): 11-16.

28. Mittal M, Kumar A, Srivastava D, Sharma P, Sharma S. Pain Perception: Computerized versus Traditional Local Anesthesia in Pediatric Patients. JOCPD $2015 ; 39(5)$.

29. Willis MH, Merkel SI, Voepel-Lewis T, Malviya S. FLACC behavioral pain assessment scale: a comparison with the child's self-report. J Pediatr Nurs 2003; 29(3): 195-198.

30. Thoppe-Dhamodharan YK, Asokan S, John BJ, Pollachi-Ramakrishnan G, Ramachandran P, Vilvanathan P. Cartiridge syringe vs computer controlled local anesthetic delivery system: pain related behavior over two sequential visits- a randomized controlle trial. J Clin Exp Dent 2015; 7(4): 513-518.

31. Ozdogan MS, Gungormus M, Ince Yusufoglu S, Ertem SY, Sonmez C, Orhan M. Salivary opiorphin in dental pain: A potential biomarker for dental disease. Arch Oral Biol 2019; 99: 15-21

32. Sumer M, Misir F, Koyuturk AE. Comparison of the Wand with a conventional technique. Oral Surg Oral Med Oral Pathol Oral Radiol Endod 2006; 101(6): 106-109.

33. Oztas N, Ulusu T, Bodur H, Doğan C. The wand in pulp therapy: an alternative to inferior alveolar nevre block. Quintessence Int 2005; 36(7): 559-564.

34. Tahmassebi JF, Nikolaou M, Duggal MS. A comparison of pain and anxiety associated with the administration of maxillary local analgesia with Wand and conventional technique. Eur Arch Paediatr Dent 2009; 10(2): 77-82.

35. Sixou JL, Marie-Cousin ALEXIA, Huet A, Hingant B, Robert JC. Pain assessment by children and adolescents during intraosseous anaesthesia using a computerized system (QuickSleeper ${ }^{\mathrm{TM}}$ ). Int J Paediatr Dent 2009; 19(5): 360-366.

36. Nusstein J, Kennedy S, Reader A, Beck M, Weaver J. Anesthetic efficacy of the supplemental X-tip intraosseous injection in patients with irreversible pulpitis. J Endod 2003; 29(11): 724-728.

37. Versloot J, Veerkamp JS, Hoogstraten J. Computerized anesthesia delivery system vs. traditional syringe: comparing pain and pain-related behavior in children. Eur J Oral Sci 2005; 113(6): 488-493.

38. Smaïl-Faugeron V, Muller-Bolla M, Sixou JL, Courson F. Evaluation of intraosseous computerized injection system (QuickSleeper ${ }^{\mathrm{TM}}$ ) vs conventional infiltration anaesthesia in paediatric oral health care: A multicentre, single-blind, combined split-mouth and parallel-arm randomized controlled trial. Int $\mathrm{J}$ Paediatr Dent 2019; 29(5): 573-584.

39. Munshi A, Hegde A, Bashir N. Clinical evaluation of the efficacy of anesthesia and patient preference using the needle-less jet syringe in pediatric dental practice. JOCPD 2002; 25(2): 131-136.

40. Smith KA, Stockman III JA, Stuart MJ, Oski FA. Jet injection anaesthesia a technique for painless bone marrow aspiration. J Pediatr 1974; 85 : 731-732

\section{Figures}




$\begin{array}{cl}\text { Information } & \text { Included patients }(n=31) \\ \text { Interview } & \text { Data loss }(n=2) \\ & \text { Having difficulty in cooperation }(n=4) \\ & \text { Withdrawn from the project voluntarily }(n=5)\end{array}$

$\mathrm{n}=20$
$8 \mathrm{G}, 12 \mathrm{~B}(\mathrm{n}=2), 9 \mathrm{~A}(\mathrm{n}=7), 10 \mathrm{~A}$ ( $\mathrm{n}=11)$

\section{Figure 1}

Patient selection and applications during treatment
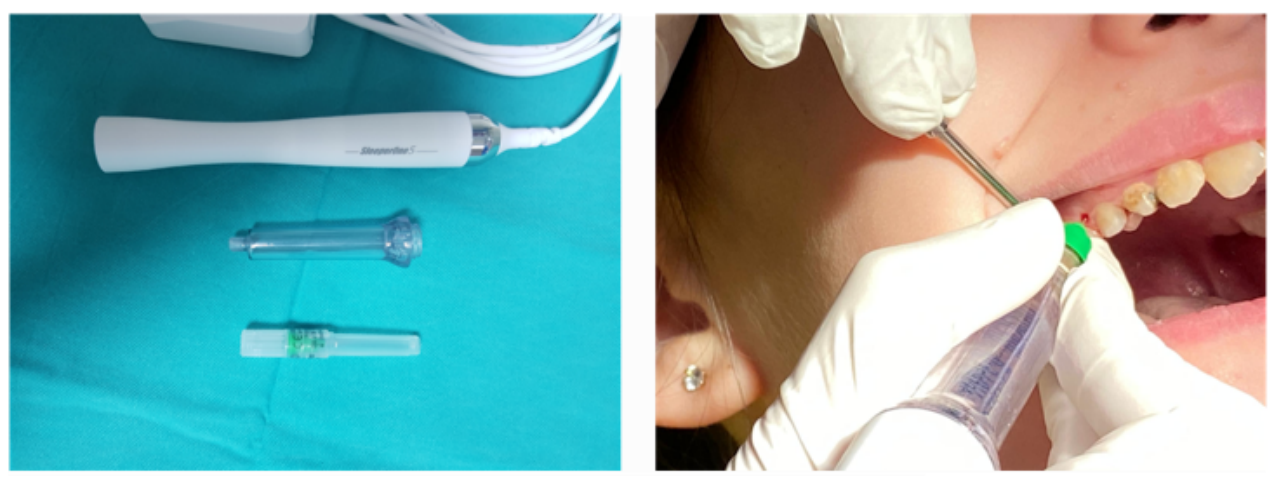

\section{Figure 2}

Intraosseous anesthesia device and its intraoral application 

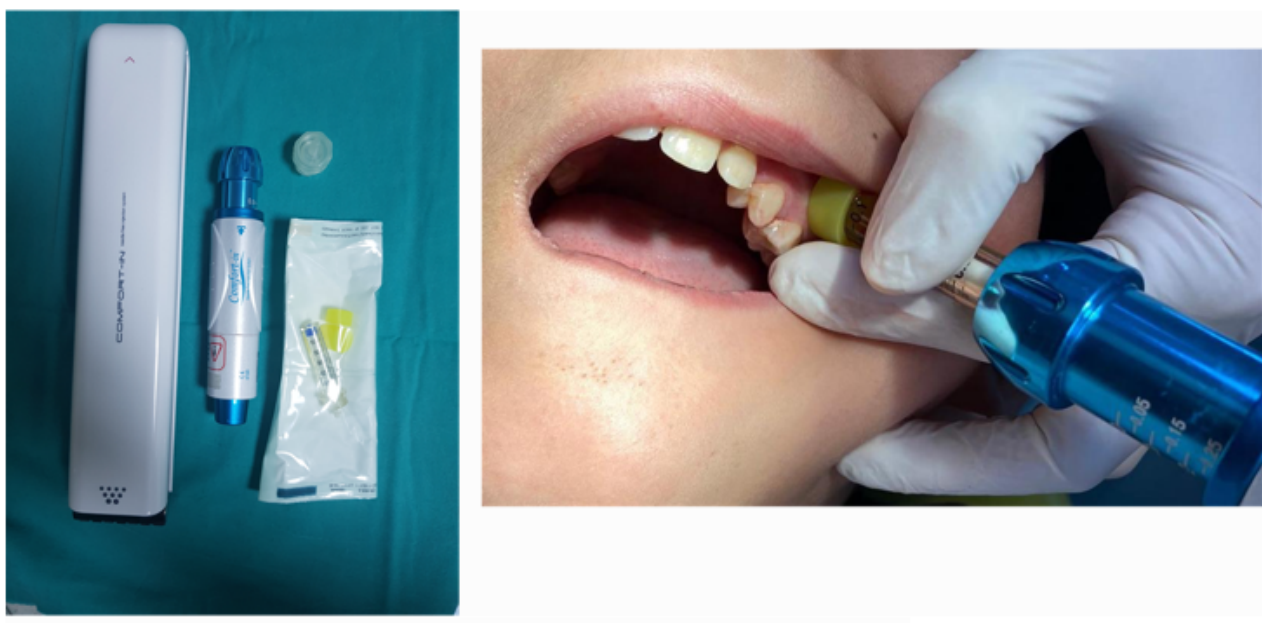

Figure 3

Needle free anesthesia device and its intraoral application

\section{Supplementary Files}

This is a list of supplementary files associated with this preprint. Click to download.

- CONSORT2010Checklist.doc

- annex1.pdf

- annex2.pdf 